\title{
Structure, Morphology, and Electrochemical Properties of Carbon-Coated Lithium-Manganese Orthosilicate with Sucrose as a Carbon Source
}

\author{
Maciej Boczar ${ }^{1}$ - Michal Krajewski ${ }^{1}$ • Bartosz Hamankiewicz ${ }^{1}$ - Maciej Ratynski ${ }^{1}$ - Dominika Buchberger ${ }^{1}$. \\ Andrzej Czerwinski ${ }^{1,2}$
}

Published online: 25 February 2020

(C) The Author(s) 2020

\begin{abstract}
Lithium-manganese orthosilicate powders were synthesized via a modified solvothermal method. Three different weight ratios of sucrose used as a carbon source were investigated for finding an effective carbon coating process. Synthesized materials were analyzed by structural and morphological (X-ray powder diffraction, scanning electron microscopy, $\mathrm{N}_{2}$ adsorption/desorption, thermogravimetry analysis) and electrochemical (chronopotentiometry, cyclic voltammetry) methods. By increasing the sucrose content, the electrochemical performance improvement of lithium-manganese orthosilicate powder was observed, such as an increase in its specific capacity $(132 \%)$ and cyclability $(5 \%)$ compared with uncoated sample. The enhancement in $\mathrm{Li}_{2} \mathrm{MnSiO}_{4}$ performance is related to an increase in its electrical conductivity and enlargement in the electrochemically active surface area due to carbon coating process.
\end{abstract}

Keywords $\mathrm{Li} 2 \mathrm{MnSiO} 4 \cdot \mathrm{Li}$-ion battery $\cdot$ Solvothermal synthesis $\cdot$ Carbon coating $\cdot$ Cathode material

\section{Introduction}

The interest in lithium-manganese orthosilicate $\left(\mathrm{Li}_{2} \mathrm{MnSiO}_{4}\right.$, LMS) has rapidly increased since the first Dominko's publication regarding the LMS compound synthesis by the modified Pechinni sol-gel process [1]. $\mathrm{Li}_{2} \mathrm{MnSiO}_{4}$ shows advantages toward commonly used positive electrode materials in Li-ion systems, such as a fast synthesis duration, low-priced substrates, and a high theoretical capacity of $333 \mathrm{mAh} \mathrm{g}^{-1}$. Such high capacity is related to the fact that one mole of $\mathrm{Li}_{2} \mathrm{MnSiO}_{4}$ can intercalate/deintercalate 2 moles of lithium ions per formula unit during galvanostatic charge/discharge processes, involving $\mathrm{Mn}^{4+} / \mathrm{Mn}^{3+}$ and $\mathrm{Mn}^{3+} / \mathrm{Mn}^{2+}$ redox couples $[1,2]$. In addition, a wide range of working potential 1.5-

Michal Krajewski

mkrajewski@chem.uw.edu.pl

1 Faculty of Chemistry, University of Warsaw, Pasteura 1, 02-093 Warsaw, Poland

2 Łukasiewicz Research Network - Industrial Chemistry Institute, Rydygiera 8, 01-793 Warsaw, Poland
4.8 V [3], low cost, and high safety of the LMS compounds arise a growing attractiveness of this material [4].

Unfortunately, the amorphization of the sample over the first charging causes a change in the crystallographic structure, and consequently a capacity drop and cyclic stability decline through following cycles. Other disadvantages of $\mathrm{Li}_{2} \mathrm{MnSiO}_{4}$ can be attributed to the differences in the structural stability of the delithiated phases, Jahn-Teller distortion of $\mathrm{Mn}^{3+}$ ions, $\mathrm{Mn}$ dissolution in the electrolyte, and low intrinsic conductivity in the range of $10^{-14}$ to $10^{-16} \mathrm{~S} \mathrm{~cm}^{-1}$ [5]. As a result, LMS exhibits reasonably good electrochemical performance only at elevated temperatures and low charge/discharge current rates. In order to improve the electrochemical parameters of lithium-manganese orthosilicate, carbon coatings were widely used with carbon sources in various forms, e.g., acetic acid [6, $7]$, adipic acid [8,9], citric acid [1, 2, 10], and sucrose [10, 11]. Moreover, the carbon coating process can be executed during the synthesis (in situ) [10] or after the completed synthesis, but before calcination (ex situ) [10,11].

Among a variety of synthesis methods, one of the most commonly used techniques to produce orthosilicates is solvo-/hydrothermal synthesis. These techniques are simple, clean, low-cost, and of low-energy consumption and are suitable to prepare high-quality materials in closed systems. In 
addition to the sol-gel methods, this technique is characterized by a very short synthesis time (several minutes for supercritical fluid techniques). Murukanahally successfully synthesized $\mathrm{Li}_{2} \mathrm{MnSiO}_{4}$ nanoparticles (4-5 nm in diameter), which showed good electrochemical performance and delivered 283/ $220 \mathrm{mAh} \mathrm{g}^{-1}$ after first and fiftieth discharge process, respectively. However, the mentioned LMS/C composite contained $\sim 18 \mathrm{wt} \%$ of amorphous carbon as a carbon coat. Muraliganth et al. obtained $\mathrm{Li}_{2} \mathrm{MnSiO}_{4} / \mathrm{C}$ powder which delivered 210 and $250 \mathrm{mAh} \mathrm{g}^{-1}$ at $\mathrm{C} / 20$ current rate in room temperature and $55^{\circ} \mathrm{C}$, respectively. The electrode polarization is greatly reduced at $55^{\circ} \mathrm{C}$ compared to room temperature experiments; however, the capacity fade of the examined lithiummanganese orthosilicate increased, and the material retained only $15 \%$ of its initial capacity after 20 cycles at elevated temperature [12]. Kuezma et al. examined the performance of $\mathrm{Li}_{2} \mathrm{MnSiO}_{4}$ at higher current rate of $\mathrm{C} / 10$ and lower potential window of $2.0-4.5 \mathrm{~V}$. The electrochemical properties of LMS powder were like Muraliganth's material, with a dramatic fall in the cyclability after fifth cycle [13]. The high discharge capacities in cited works are due to a high phase purity and monodispersed nanoparticles of lithium-manganese orthosilicate powders, which facilitate short reaction pathways for the lithium insertion/exertion process $[14,15]$.

Most of the $\mathrm{Li}_{2} \mathrm{MnSiO}_{4} / \mathrm{C}$ composites obtained through solvo- and hydrothermal reactions contain relatively huge amounts of amorphous carbon. Kempaiah et al. synthesized LMS/C compound through solvothermal process with 13.3 wt $\%$ amorphous carbon [14]. Composite obtained by Devaraju et al. contained $18 \mathrm{wt} \%$ of carbonaceous modifications [16]. Muraliganth et al. prepared $\mathrm{Li}_{2} \mathrm{MnSiO}_{4} / \mathrm{C}$ composite by solvothermal reaction with $12 \mathrm{wt} \%$ of amorphous carbon through sucrose reduction [12]. Such high amounts of electrochemically inactive species in the electrode lead to limited gravimetric capacity of the cell.

In this work, we examined the effect of the sucrose additive on final $\mathrm{Li}_{2} \mathrm{MnSiO}_{4} / \mathrm{C}$ material. Sucrose was used as a carbon coating source in this modified solvothermal synthesis. The amorphous carbon in prepared composites was on low level (1-3 wt\%), demonstrating its positive effect on structural, morphological, and electrochemical properties of this new LMS positive electrode material for lithium-ion cells.

\section{Experimental}

\section{Synthesis of $\mathrm{Li}_{2} \mathrm{MnSiO}_{4}$ by Solvothermal Method}

$\mathrm{Li}_{2} \mathrm{MnSiO}_{4} / \mathrm{C}$ composite was synthesized by a solvothermal method. The schematic of the synthesis steps is shown in Fig. 1. Firstly, $0.0368 \mathrm{~mol} \mathrm{Si}\left(\mathrm{OC}_{2} \mathrm{H}_{5}\right)_{4}$ (TEOS, SigmaAldrich) was dissolved in $40 \mathrm{ml}$ of ethyl alcohol (EtOH, $\mathrm{POCH}$ ) and $25 \mathrm{ml}$ of deionized water and then mixed with

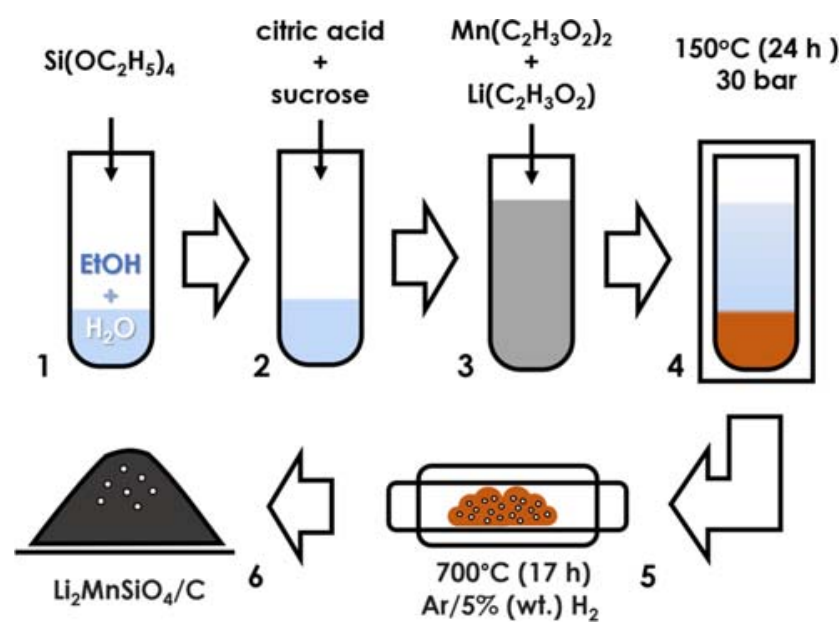

Fig. 1 Schematic representation of the synthesis procedure

$0.015 \mathrm{~mol}$ of citric acid (Sigma-Aldrich) and either 0.001, 0.002 , or $0.003 \mathrm{~mol}$ of sucrose (Sigma-Aldrich) for SLMS1, SLMS2, or SLMS3 samples, respectively. Then, $0.0386 \mathrm{~mol}$ of ethylene glycol $(\mathrm{POCH})$ were added to the so-prepared solutions (solution $\mathrm{A}$ ). The mixtures were then sonicated on ultrasonic scrubber for $30 \mathrm{~min}$ and heated to $30^{\circ} \mathrm{C}$ to combine the reagents. $0.0372 \mathrm{~mol}$ of $\mathrm{Mn}\left(\mathrm{C}_{2} \mathrm{H}_{3} \mathrm{O}_{2}\right)_{2} \cdot 4 \mathrm{H}_{2} \mathrm{O}$ (SigmaAldrich) and $0.0761 \mathrm{~mol}$ of $\mathrm{Li}\left(\mathrm{C}_{2} \mathrm{H}_{3} \mathrm{O}_{2}\right) \cdot 2 \mathrm{H}_{2} \mathrm{O}$ (SigmaAldrich) were separately dissolved (solutions $\mathrm{B}$ and $\mathrm{C}$ ) in identical solvent mixtures: $40-\mathrm{ml} \mathrm{EtOH}$ and $25 \mathrm{ml}$ of deionized water. Then solutions $B$ and $C$ were both added dropwise to the previously prepared solutions (A). The final solution, containing hydrolyzed $\mathrm{SiO}_{2}$ from TEOS, was moved to the reactor and heated to $150{ }^{\circ} \mathrm{C}$ for $24 \mathrm{~h}$ under 30 bar pressure. The resulting gels were heat-treated in the tubular oven for $17 \mathrm{~h}$ at $700{ }^{\circ} \mathrm{C}$ in a reducing atmosphere of $\mathrm{Ar} / 5 \mathrm{wt} \% \mathrm{H}_{2}$ to form a carbon-coated $\mathrm{Li}_{2} \mathrm{MnSiO}_{4}$.

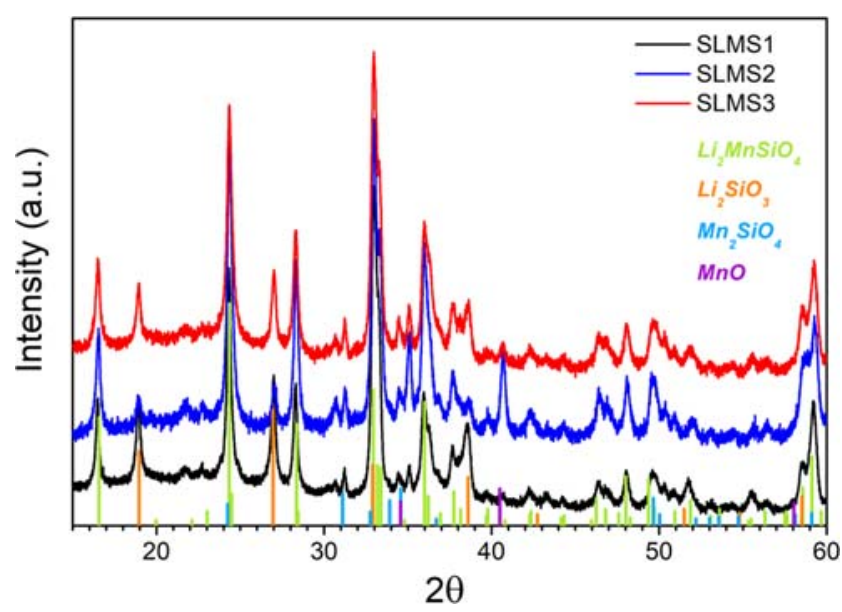

Fig. 2 XRD patterns of all $\mathrm{Li}_{2} \mathrm{MnSiO}_{4}$ powders. All detected phases are marked using different colors, namely, $\mathrm{Li}_{2} \mathrm{MnSiO}_{4}$ (green), $\mathrm{Mn}_{2} \mathrm{SiO}_{4}$ (blue), $\mathrm{MnO}$ (purple), and $\mathrm{Li}_{2} \mathrm{SiO}_{3}$ (orange). $\mathrm{Cu}$ lamp charged with $40 \mathrm{~mA}$ and $40 \mathrm{kV}$; measurement done in the range of $10^{\circ}$ to $120^{\circ}$ with a step of $0.008^{\circ}$ 


\section{Structural and Morphological Analyses}

$\mathrm{X}$-ray diffraction (XRD) measurements were carried out in the classical Bragg-Brentano geometry. $\mathrm{X}$-ray tube $\mathrm{C}$ was used in the optical system of the 1-degree slit and Ni filter (1:20). The copper $(\mathrm{Cu})$ lamp was charged with $40 \mathrm{~mA}$ and $40 \mathrm{kV}$. Measurements were done in the $2 \theta$ range of $10^{\circ}-120^{\circ}$ with a step of $0.008^{\circ}$.

Merlin scanning electron microscope (Zeiss) was used together with a Quantax 400 energy dispersive X-ray spectroscope (Bruker) in SEM and EDX measurements. Electron beam energy used for X-ray excitation was $3 \mathrm{keV}$. The sample image was obtained from the resultant of two in-lens and secondary electron detectors in order to obtain the best contrast.

Thermal stability of carbon products was studied by thermogravimetry (TGA) using a TA Q50 instrument. The measurements were performed under oxidizing atmosphere $\left(\mathrm{N}_{2}: \mathrm{O}_{2} 95: 5 \mathrm{vol} \%\right)$ with the heating rate of $10{ }^{\circ} \mathrm{C} \mathrm{min}^{-1}$.

The Micromeritics ${ }^{\circledR}$ ASAP 2060 apparatus, at $77.349 \mathrm{~K}$ in the range of 0.01 to 0.995 relative $\mathrm{N}_{2}$ pressure $\mathrm{p} \cdot\left(\mathrm{p}^{0}\right)^{-1}$ equipment, was used to evaluate adsorption/desorption of $\mathrm{N}_{2}$. ASAP software was used for data processing. The surface area was obtained using the BET method, whereas a distribution and pore volume were calculated using the BJH method for desorption curves and $\mathrm{H}-\mathrm{K}$ for microporous systems. Moreover, ASAP software was used to estimate average grain size of LMS powders, assuming powder density of $4.0 \mathrm{~g} \mathrm{~cm}^{-3}$.

\section{Electrochemistry}

The orthosilicate powders were used for electrochemical tests. Firstly, the sample (active material) was homogenized with Vulcan XC72R carbon (conductive additive) for $15 \mathrm{~min}$ in

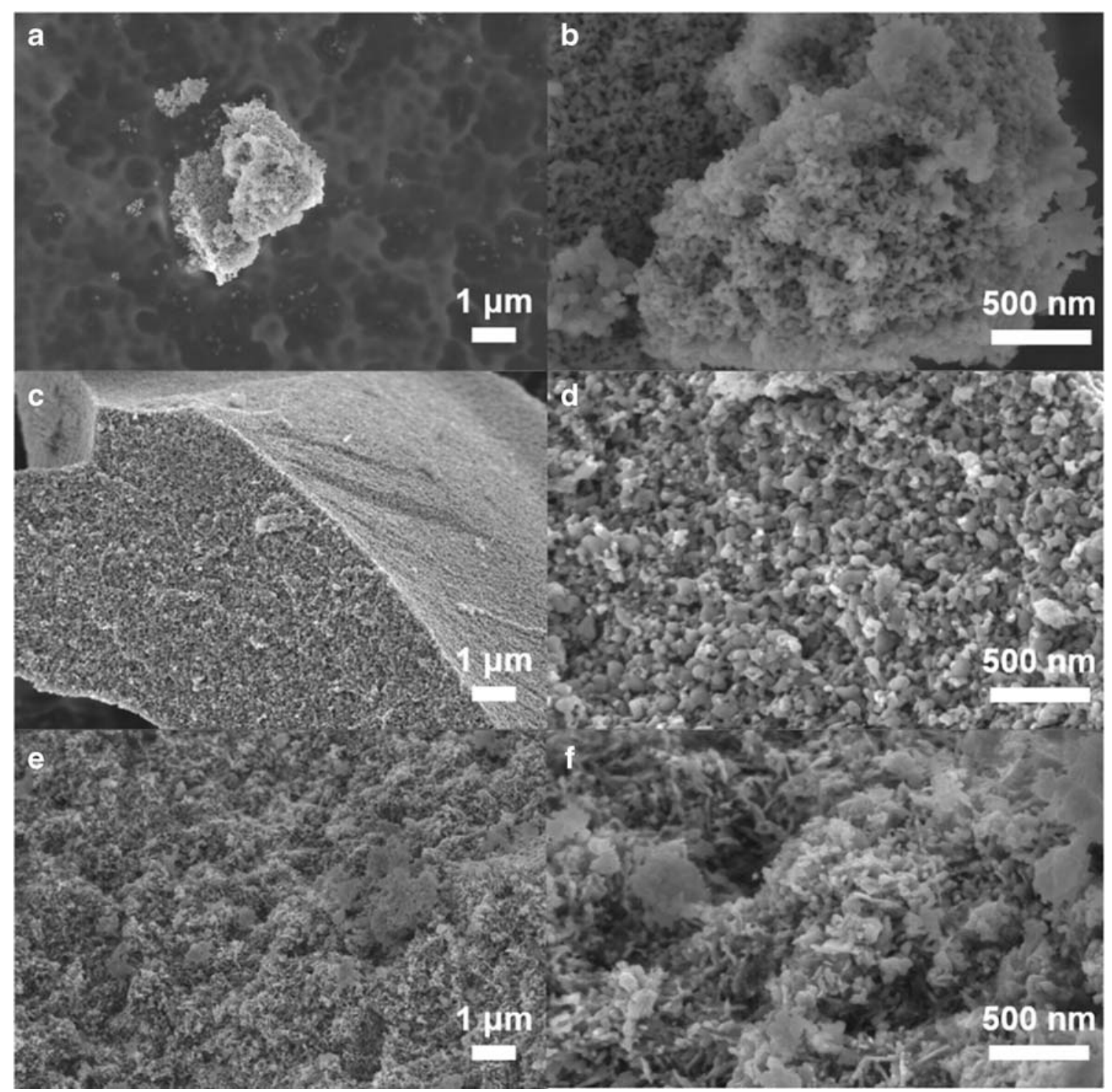

Fig. 3 SEM images of SLMS1 (a, b), SLMS2 (c, d), and SLMS3 (e, f) powders. Beam energy was 3-5 keV; spectrum acquisition was ca. $120 \mathrm{~s}$ 
an agate mortar. As-prepared blend was mixed with $5 \mathrm{wt} \%$ PVDF solution (dissolved in N-methyl-2-pyrrolidone) and stirred on a magnetic stirrer to unify the slurry. This mixture was then applied on to the aluminum foil with automatic applicator and, in order to evaporate the residual solvent, dried in vacuum at $120{ }^{\circ} \mathrm{C}$ overnight. Electrodes were cut from the layer, compressed at 200 bar, weighed, and re-dried in a vacuum. Such prepared samples were transported to the glove box (MBraun Unilab MB-20-G).

The electrochemical performance of $\mathrm{Li}_{2} \mathrm{MnSiO}_{4}$ powders was tested in a Swagelok ${ }^{\circledR}$-type three-electrode system. $\mathrm{Li}_{2} \mathrm{MnSiO}_{4}$ electrodes were used as the working electrodes,
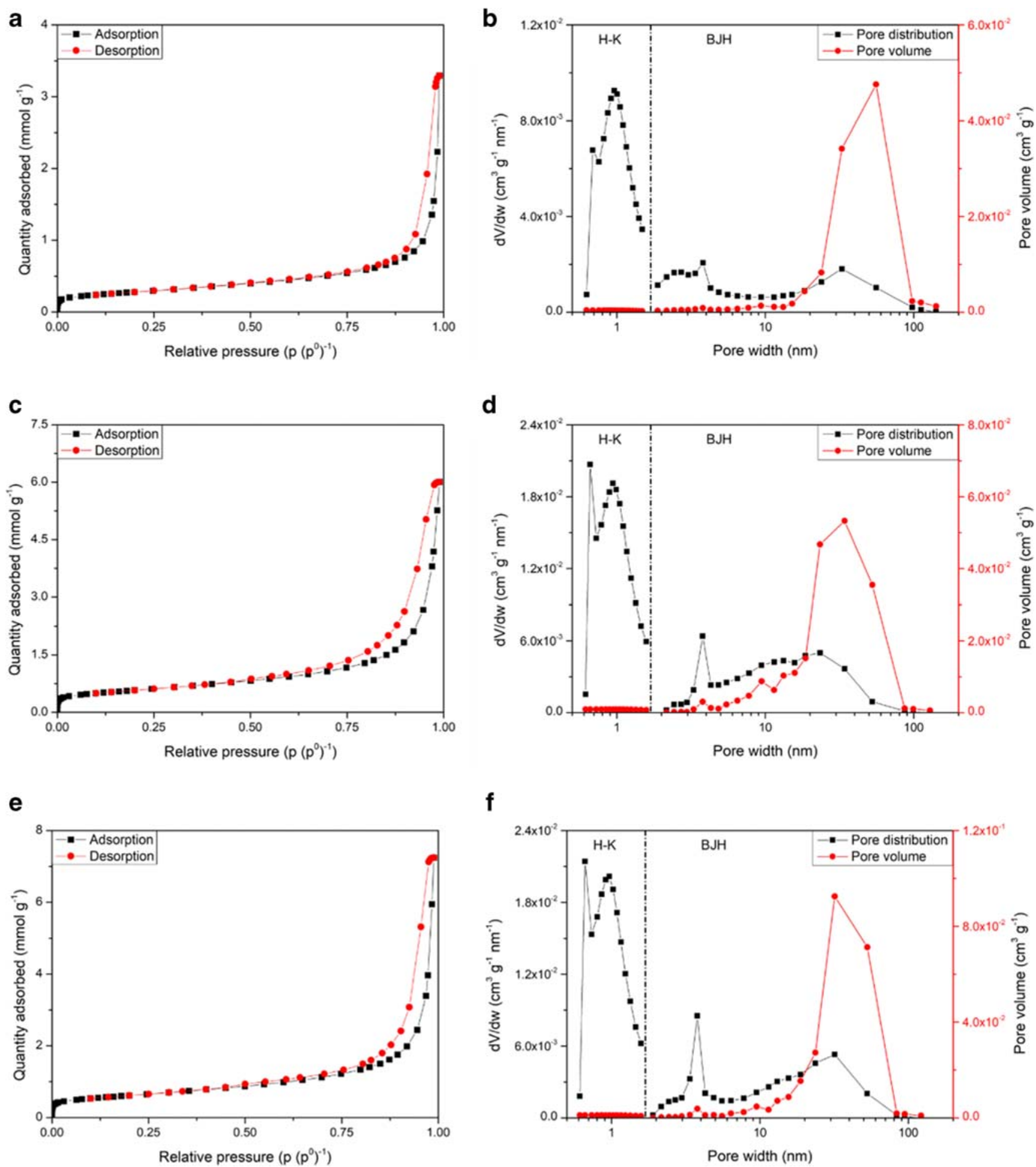

Fig. $4 \mathrm{~N}_{2}$ adsorption/desorption isotherms (a, c, e) and pore distribution (b, d, f) for HLMS1 (a, b), HLMS2 (c, d), and HLMS3 (e, f) powders 
Table 1 Active surface area and pore distribution studies on $\mathrm{Li}_{2} \mathrm{MnSiO}_{4}$ powders

\begin{tabular}{llllll}
\hline Sample & BET surface area $\left[\mathrm{m}^{2} \mathrm{~g}^{-1}\right]$ & Dominant pores $[\mathrm{nm}]$ & $\begin{array}{l}\text { Pore volume } \\
(1.7-300 \mathrm{~nm})\left[\mathrm{cm}^{3} \mathrm{~g}^{-1}\right]\end{array}$ & $\begin{array}{l}\text { Pore volume } \\
\left(<1.7 \mathrm{~nm}^{[}\left[\mathrm{cm}^{3} \mathrm{~g}^{-1}\right]\right.\end{array}$ & $\begin{array}{l}\text { Average particle } \\
\text { size }[\mathrm{nm}]\end{array}$ \\
\hline SLMS1 & $22.15 \pm 0.06$ & $0.6-0.7 ; 0.9-1.0 ; 3-4 ; 20-40$ & 0.1126 & 0.0061 & 68 \\
SLMS2 & $45.89 \pm 0.11$ & $0.6-0.7 ; 0.9-1.0 ; 3-4 ; 20-40$ & 0.2072 & 0.0136 & 33 \\
SLMS3 & $48.75 \pm 0.15$ & $0.6-0.7 ; 0.9-1.0 ; 3-4 ; 20-40$ & 0.2489 & 0.0145 & 31 \\
\hline
\end{tabular}

whereas metallic lithium acts as the counter and reference electrodes. Trilayer separators (polypropylene (PP) polyethylene (PE) polypropylene (PP)) of $25 \mu \mathrm{m}$ thickness (Celgard $\AA 2325$ ) were immersed in $1 \mathrm{M} \mathrm{LiPF}_{6}$ dissolved in ethylene carbonate and dimethyl carbonate (1:1 wt./wt., BASF). Galvanostatic charge/discharge tests and cyclic voltammetry (CV) were tested on multichannel battery tester Sollich Atlas 1361 and Solartron SI 1287 Electrochemical Interface. Chronopotentiometry (CP) charge/discharge experiments were made in the potential range of 1.5 and $4.8 \mathrm{~V}\left(\mathrm{vs} . \mathrm{Li}^{+} / \mathrm{Li}^{0}\right)$ for 20 cycles at $0.1 \mathrm{C}$ current rate (where $\mathrm{C}$ corresponds to $333 \mathrm{~mA} \mathrm{~g}^{-1}$ ) at room temperature. Similarly, in case of CV measurements, the working electrode was polarized between 1.5 and $4.8 \mathrm{~V}\left(\mathrm{vs} . \mathrm{Li}^{+} / \mathrm{Li}^{0}\right)$ at a scan rate of $0.1 \mathrm{mV} \mathrm{s}^{-1}$ for 2 cycles.

\section{Results and Discussion}

\section{Structure and Morphology of $\mathrm{Li}_{2} \mathrm{MnSiO}_{4} / \mathrm{C}$ Composites}

\section{Structural and Morphological Analyses of SLMS Samples}

Figure 2 presents XRD patterns of $\mathrm{Li}_{2} \mathrm{MnSiO}_{4} / \mathrm{C}$ powders. The main phase in all analyzed SLMS samples was identified as lithium-manganese orthosilicate (ICSD 98-026-2720; Pnma space group) as expected [17]. The additional reflexes originating from impurities, such as $\mathrm{MnO}, \mathrm{Li}_{2} \mathrm{SiO}_{3}$, and $\mathrm{Mn}_{2} \mathrm{SiO}_{4}$, were present in the examined powders. The

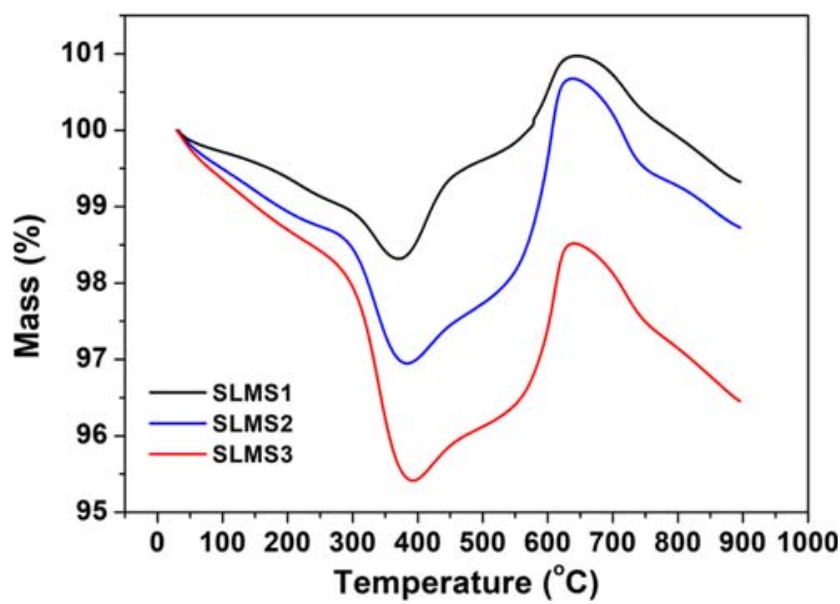

Fig. 5 TGA of $\mathrm{Li}_{2} \mathrm{MnSiO}_{4}$ powders synthesized by a modified solvothermal method with sucrose as a carbon source dominant impurity phase in SLMS1 powder consisted of $\mathrm{Li}_{2} \mathrm{SiO}_{3}$, while $\mathrm{MnO}$ and $\mathrm{Mn}_{2} \mathrm{SiO}_{4}$ were mostly present in SLMS2 and SLMS3 composites. The lowest amount of the impurity phases were characterized in the SLMS3 sample. This suggests that a sucrose addition reduces the amount of contaminations obtained during solvothermal synthesis process, due to separation of ions in the xerogel and gas evolution processes during heat treatment [18, 19]. The crystallite size of SLMS samples was estimated from the Scherrer's equation. The calculated crystallite sizes were found to be $40 \mathrm{~nm}, 33 \mathrm{~nm}$, and $33 \mathrm{~nm}$ for SLMS1, SLMS2, and SLMS3, respectively.

The SEM images of $\mathrm{Li}_{2} \mathrm{MnSiO}_{4}$ powders are shown in Fig. 3. A uniform distribution of material grains in the range of 10 to $100 \mathrm{~nm}$ were in all the synthesized samples. Some agglomeration and a creation of cubic and pellet-like structures (up to few hundred nanometers in diameter) were also visible on the recorded SEM images.

\section{Active Surface Area and Pore Distribution Studies}

Figure 4 shows $\mathrm{N}_{2}$ adsorption/desorption isotherms and a pore distribution of $\mathrm{Li}_{2} \mathrm{MnSiO}_{4}$ powders. The adsorption curves presented a course similar to Brauner's type-II isotherms, while at the same time the desorption isotherm did not overlap with adsorption one. The IUPAC type-H3 of hysteresis loop suggested a slit-shape geometry of pores present in analyzed powders [20]. BET-specific surface area (SSA) calculations showed an increase in $\mathrm{Li}_{2} \mathrm{MnSiO}_{4}$ powders SSA with an increased amount of carbon source added into the solvothermal reactor. Calculated BET-specific surface area for LMS powders was found to be $22.15 \pm 0.06,45.89 \pm 0.11$, and $48.75 \pm$ $0.15 \mathrm{~m}^{2} \mathrm{~g}^{-1}$ for SLMS1, SLMS2, and SLMS3 powders, respectively. One can see that a small carbon addition can improve the SSA by a factor of over two.

Pore distribution in examined powders displayed a similar trend in every analyzed sample. One can see four dominant pore ranges: $0.6-0.7,0.9-1.0,3-4$, and $20-40 \mathrm{~nm}$. Pore volumes calculated during adsorption/desorption experiments increased in value as the sucrose content in the reactor increased. The highest volumes were found to be 0.2489 and $0.0145 \mathrm{~cm}^{3} \mathrm{~g}^{-1}$ for SLMS3 powder and pore diameter of 1.7-300 and <1.7 nm, respectively. Moreover, SLMS3 composite showed lowest average grain size calculated from 

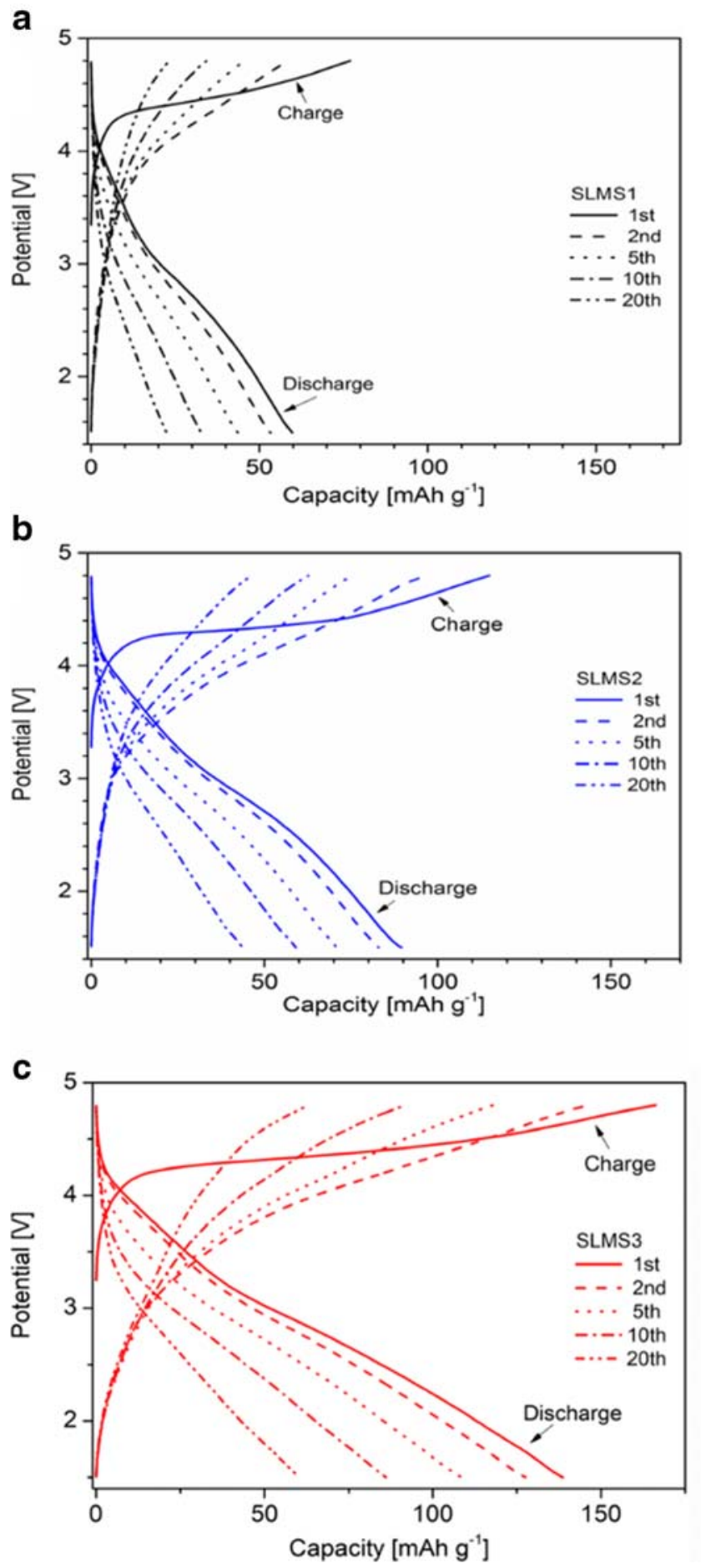

Fig. 6 Charge/discharge curves $(\mathbf{a}-\mathbf{c})$ of $\mathrm{Li}_{2} \mathrm{MnSiO}_{4}$ powders (solid line, 1 st cycle; dashed line, 2nd cycle; shortly dashed line, 5th cycle; dashed dot line, 10th cycle; dashed dot dot line, 20th cycle). Cyclability of $\mathrm{Li}_{2} \mathrm{MnSiO}_{4}$ powders during charge (d) and discharge (e) processes

adsorption/desorption analysis, reaching $31 \mathrm{~nm}$ in diameter. This value is comparable to the XRD findings and combined with SEM observations suggests most homogenous distribution of $\mathrm{Li}_{2} \mathrm{MnSiO}_{4}$ particles. The results of $\mathrm{N}_{2}$ adsorption/ desorption experiments are also listed in Table 1.

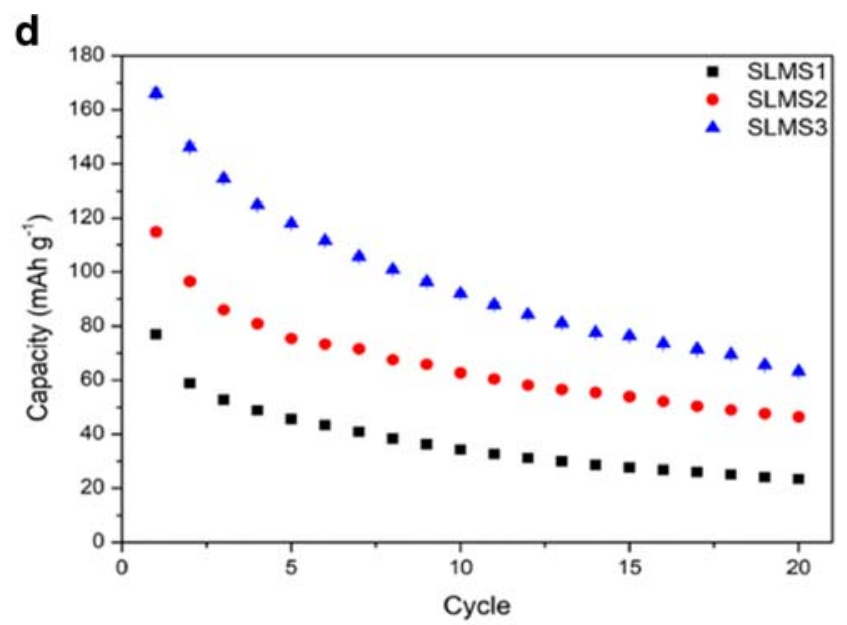

e
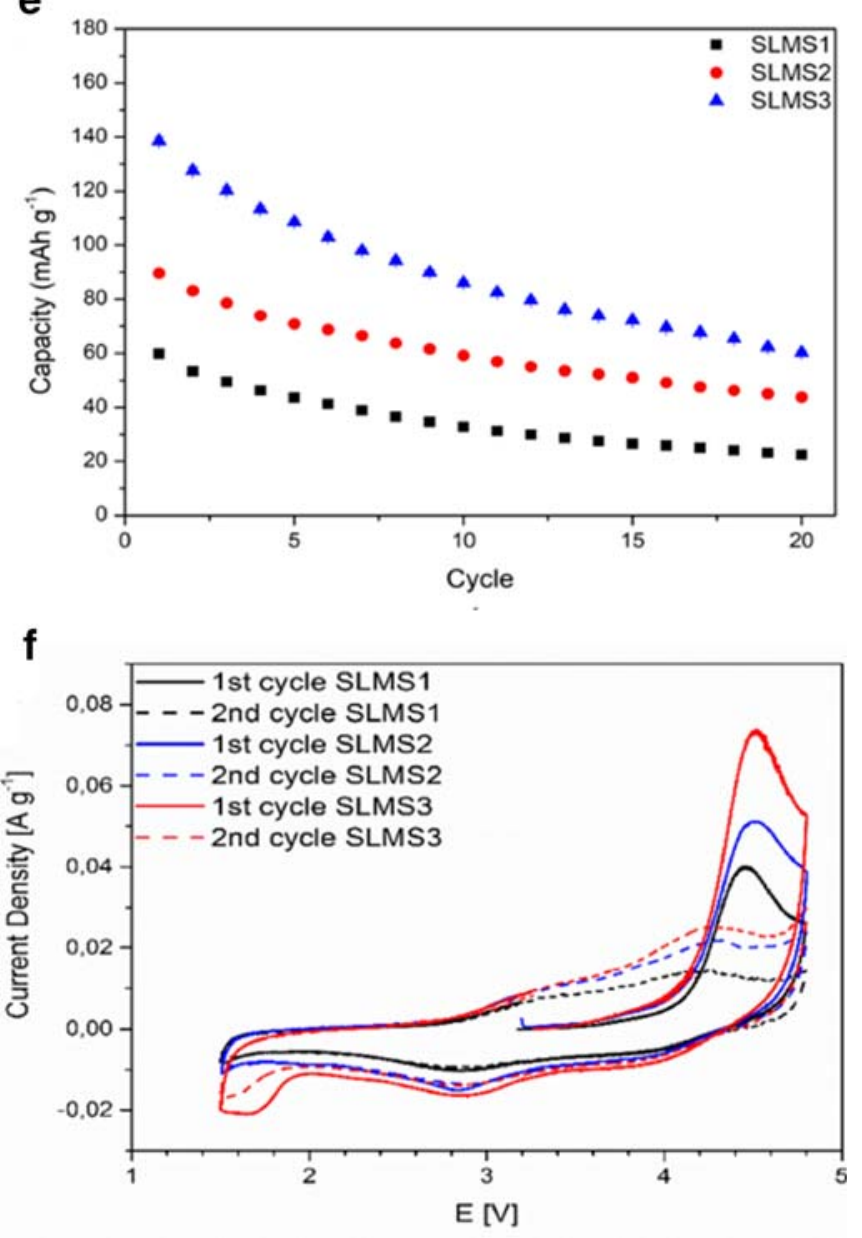

(charge/discharge current, $\mathrm{C} / 10$; potential range, from 1.5 to $4.8 \mathrm{~V}$ vs. $\left.\mathrm{Li}^{+} / \mathrm{Li}^{0}\right)$. Cyclic voltamperometry curves (a) of $\mathrm{Li}_{2} \mathrm{MnSiO}_{4}$ powders (scan rate, $0.1 \mathrm{mV} \mathrm{s}^{-1}$; potential range, from 1.5 to $4.8 \mathrm{~V} \mathrm{vs} . ~ \mathrm{Li}^{+} / \mathrm{Li}^{0}$ )

\section{Carbon Content Analysis Through TGA Experiments}

Thermogravimetric analysis is a very common technique used for a determination of carbon content in the sample. Generally, when the sample is exposed to oxygen (air) atmosphere during 
Table 2 Chronopotentiometric results of $\mathrm{Li}_{2} \mathrm{MnSiO}_{4}$ powders

\begin{tabular}{lllll}
\hline Material & $\begin{array}{l}\text { Electrode loading } \\
( \pm 0.02)\left[\mathrm{mg} \mathrm{cm}^{-2}\right]\end{array}$ & $\begin{array}{l}\text { First charge/discharge } \\
\text { capacity }\left[\mathrm{mAh} \mathrm{g}^{-1}\right]\end{array}$ & $\begin{array}{l}\text { 20th charge/discharge } \\
\text { capacity }\left[\mathrm{mAh} \mathrm{g}^{-1}\right]\end{array}$ & $\begin{array}{l}\text { Discharge capacity retained } \\
\text { after 20th cycle }( \pm 0.1)[\%]\end{array}$ \\
\hline SLMS1 & 2.17 & $76.9 \pm 0.7 / 59.8 \pm 0.5$ & $23.3 \pm 0.2 / 22.5 \pm 0.2$ & 37.6 \\
SLMS2 & 1.62 & $114.9 \pm 1.4 / 89.5 \pm 1.1$ & $46.4 \pm 0.6 / 43.8 \pm 0.5$ & 48.9 \\
SLMS3 & 2.00 & $166.2 \pm 1.6 / 138.6 \pm 1.4$ & $63.2 \pm 0.6 / 60.3 \pm 0.6$ & 43.5 \\
\hline
\end{tabular}

the TGA analysis, the carbon decomposition starts above $200{ }^{\circ} \mathrm{C}$ and up to $400{ }^{\circ} \mathrm{C}$ [21]. Figure 5 shows that the carbon content in our $\mathrm{Li}_{2} \mathrm{MnSiO}_{4}$ composite is close to $1 \mathrm{wt} \%$ for SLMS1, about $1.75 \mathrm{wt} \%$ for SLMS2, and above $3 \mathrm{wt} \%$ for SLMS3. At around $550{ }^{\circ} \mathrm{C}$, the weight gain corresponded to the increase of oxygen mass derived from the crystal transformation of $\mathrm{MnO}$ impurity phase into $\mathrm{Mn}_{2} \mathrm{O}_{3}$.

\section{Electrochemistry}

\section{Galvanostatic Charge/Discharge Tests}

The results of galvanostatic charge/discharge tests for $\mathrm{Li}_{2} \mathrm{MnSiO}_{4}$ powders are presented in Fig. 6 a to e and Table 2. Capacities delivered during the first charge/ discharge cycle were 77/60, 115/90, and 166/139 $\mathrm{mAh} \mathrm{g}^{-1}$ for SLMS1, SLMS2, and SLMS3 powders, respectively. Increasingly, the sucrose content resulted in an enhancement of LMS electrochemical activity. The capacity increase during the first charge/discharge cycle can be assigned to the enhanced electronic conductivity and electron transport through $\mathrm{Li}_{2} \mathrm{MnSiO}_{4}$ electrodes. This is because of an improved electrochemically active surface area of LMS grains [22]. During a continuous charge/discharge cycling, one can see a rapid drop of specific capacity in lithium-manganese orthosilicate powders. This phenomenon can be related to the phase amorphization during the first charge process [23, 24] and the continuous crystal degradation due to the Jahn-Teller effect of Mn ions and manganese dissolution into the electrolyte [23]. After twenty charge/discharge cycles, the examined powders delivered capacities of $23 / 23,46 / 40$, and $63 /$ $60 \mathrm{mAh} \mathrm{g}^{-1}$ and thus retained $38 \%, 49 \%$, and $43 \%$ of their initial capacity for SLMS1, SLMS2, and SLMS3 powders, respectively. As concluded from SEM and $\mathrm{N}_{2}$ adsorption/ desorption experiments, increasing the amount of sucrose in the reactant mixture results in reduced grain size of synthesized powders. Therefore, by reduction of the $\mathrm{Li}_{2} \mathrm{MnSiO}_{4}$ particle size, the diffusion pathways for $\mathrm{Li}^{+}$ions can be shortened. This would enhance the lithium ion transport properties, increase the contact area with the electrolyte, and improve the electrical conductance of the electrode through the conductive carbon network.

One can see that even though SLMS3 powder shows the best electrochemical performance (the highest specific capacity), its cyclability is lower than SLMS2 compound. This phenomenon can be explained by longer periods of time, during which SLMS3 compound was present in the potentials above $4.5 \mathrm{~V}$ (vs. $\left.\mathrm{Li}^{+} / \mathrm{Li}^{0}\right)$. Since the conventional electrolyte mixture of $1 \mathrm{M} \mathrm{LiPF}_{6}$ in EC/DMC starts to decompose above $4.5 \mathrm{~V}$ (vs. $\mathrm{Li}^{+} / \mathrm{Li}^{0}$ ) $[23,25]$, the cell with SLMS3 powder could produce more electrolyte decomposition products. As it was exposed to those potentials for the extended time (due to its improved capacity reached at such high potentials), which in turn caused highest degree of electrolyte decomposition [25], it induced a faster electrode degradation. However, this trend requires a further examination.

The diminishing of the synthetic method to the nanoscale results in the shortening of the lithium ion diffusion pathway and thus accelerates the intercalation/deintercalation process. Table 3 shows the results of solvo- and hydrothermal

Table 3 Electrochemical properties of $\mathrm{Li}_{2} \mathrm{MnSiO}_{4}$ synthesized by solvothermal and hydrothermal methods

\begin{tabular}{|c|c|c|c|c|c|c|c|}
\hline Work & Synthesis method & Carbon source & $\begin{array}{l}\text { Carbon content } \\
\text { analyses }(\%)\end{array}$ & C-rate & $\begin{array}{l}\text { First discharge } \\
\text { capacity }\left(\mathrm{mAh} \mathrm{g}^{-1}\right)\end{array}$ & 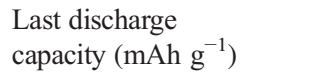 & $\begin{array}{l}\text { Potential } \\
\text { window (V) }\end{array}$ \\
\hline$[12]$ & Solvothermal & $30 \%$ sucrose (ex) & 12 TGA & $\mathrm{C} / 20$ & $\mathrm{D} 1: 210 \mathrm{RT}, \mathrm{D} 1: 25055^{\circ} \mathrm{C}$ & D10:150, D10:65 & $1.5-4.7$ \\
\hline [13] & Solvothermal & GA + citric acid & $\begin{array}{c}\text { 1CA } 10.55 \mathrm{CA} \\
31.7 \mathrm{ICP} \\
\text { analysis }\end{array}$ & $\mathrm{C} / 10$ & $\mathrm{D} 1: 25050{ }^{\circ} \mathrm{C}$ & D5:65 & $2.0-4.5$ \\
\hline [14] & Hydrothermal & $20 \%$ PEDOT (ex) & 13.3 TGA & $\mathrm{C} / 20$ & $\mathrm{D} 1: 280 \mathrm{RT}, \mathrm{D} 1: 30040{ }^{\circ} \mathrm{C}$ & D20:140 RT, D20:230 $40^{\circ} \mathrm{C}$ & $1.5-4.5$ \\
\hline$[15]$ & Hydrothermal & $\begin{array}{c}10 \% \text { PEDOT }+5 \% \\
\text { MWCNT }(\mathrm{ex})\end{array}$ & not provided & $\mathrm{C} / 50$ & $\mathrm{D} 1: 130 \mathrm{RT}, \mathrm{D} 1: 35045^{\circ} \mathrm{C}$ & $\begin{array}{l}\text { D2:210 RT, D20:300 } 40 \\
{ }^{\circ} \mathrm{C} \text { D2 } 1: 157\end{array}$ & $1.5-4.8$ \\
\hline$[16]$ & Solvothermal & $\begin{array}{c}10 \% \text { PeDOT }+10 \% \\
\text { Carbon Black }\end{array}$ & 18 TGA & $\mathrm{C} / 20$ & D1:283 & D50:220 & $1.5-4.8$ \\
\hline Our work & Solvothermal & sucrose + citric acid & $\begin{array}{l}1 \text { TGA, } 2 \text { TGA, } \\
3.5 \text { TGA }\end{array}$ & $\mathrm{C} / 10$ & D1:60,D1:90, D1:139 & D20:23,D20:44, D20:60 & $1.5-4.8$ \\
\hline
\end{tabular}


syntheses. Increasing the working temperature of the cell causes a reduction in viscosity which causes a faster diffusion of lithium ions. With the increase of the working temperature of the system, we also accelerate aging of the cell and increase the rate of electrolyte decomposition. The carbon additives such as PEDOT, carbon black, sucrose, citric acid, etc. improve the poor conductivity of the material based on orthosilicates. The improvement of the cell's capacity has been achieved by increasing the working temperature of the cell $[12,14,15]$. The temperature increase caused faster aging of the battery, which may be the result of faster electrolyte degradation. The best results, due to the carbon content, were achieved between 13 and $18 \mathrm{wt} \%$ [13, 15, 26]. Too little amount of conductive carbon additive does not allow good conductivity to be obtained from all grains, while too much carbon content forms agglomerates from amorphous carbon, which inhibits lithium ion diffusion. In our work, it has been presented how a small addition of sucrose (1-3\%) to the synthesis improves the electrochemical parameters of the cell in contrast to other works where the carbon is added after the gel is formed, i.e., only on the outer coating.

\section{Cyclic Voltammetry}

Figure $6 \mathrm{f}$ presents cyclic voltammograms of $\mathrm{Li}_{2} \mathrm{MnSiO}_{4}$ powders. A large oxidation peak at ca. $4.5 \mathrm{~V}\left(\mathrm{vs} . \mathrm{Li}^{+} / \mathrm{Li}^{0}\right)$ during the first oxidation process shifted to lower potential values and then to lower current densities in subsequent cycle. These phenomena might be correlated to lithium-manganese orthosilicate phase amorphization happening during first charging process. After the initial LMS amorphization, the shape of voltammograms changed exposing two redox pairs present at 2.9/3.2 and 4.0/4.3 V (vs. $\left.\mathrm{Li}^{+} / \mathrm{Li}^{0}\right)$ and related to $\mathrm{Mn}^{2+} / \mathrm{Mn}^{3+}$ and $\mathrm{Mn}^{3+} / \mathrm{Mn}^{4+}$ redox processes. Moreover, when the electrode potential approached to $4.6 \mathrm{~V}$ (vs. $\mathrm{Li}^{+}$/ $\mathrm{Li}^{0}$ ), there was an increase in the current density flowing through the electrochemical cell, which can be related to electrolyte decomposition reactions at high potentials as suggested before. In the case of SLMS3 sample, one can see one additional reduction process, present below $1.8 \mathrm{~V}\left(\mathrm{vs} \mathrm{Li}^{+} / \mathrm{Li}^{0}\right)$, which could be related to unreacted contaminations in SLMS3 powder, which started to be visible on voltammograms due to enhanced conductivity through the electrode (as the amorphous carbon obtained from the sucrose reduction started to provide electrical connection between current collector, orthosilicate particles, and impurities present in the sample). The current density values for $\mathrm{Li}_{2} \mathrm{MnSiO}_{4} / \mathrm{C}$ composites increased together with the amount of sucrose added into the reactor chamber, suggesting enhanced kinetics of lithium insertion/extraction reaction into/out of lithiummanganese orthosilicate grains. This effect supports findings from galvanostatic charge/discharge test and is related to the enhanced conductivity of LMS electrodes, suggesting an increase in their electrochemically active surface area $[10$, 26-29].

\section{Conclusions}

In our work, we synthesized and characterized a series of lithium-manganese orthosilicate powders with a various carbon content. Use of the modified solvothermal method with sucrose as a carbon source led to a good quality $\mathrm{Li}_{2} \mathrm{MnSiO}_{4}$ powder with a small amount of impurities and enhanced electrochemical performance in lithium-ion cell. The increased amount of the carbon source used in solvothermal process significantly changed the LMS material properties such as improved electrochemical properties of LMS/C compounds, reduced grain size, and increased their specific surface area. A small particle size and large specific surface area, altogether with internal carbon coating, increased lithium-manganese orthosilicate electrochemically active surface area, which was responsible for an enhancement in LMS electrochemical performance. It is noteworthy that despite the improvement in $\mathrm{Li}_{2} \mathrm{MnSiO}_{4}$ properties, we observed a decrease in cycling stability related to a prolonged electrolyte decomposition at high potentials. Nonetheless, our work shows that modified solvothermal process with sucrose as a carbon source is an effective, fast, and cheap approach to manufacture a new generation of electrode materials for lithium-ion batteries.

Funding information This work was supported by The Polish National Centre of Science through the research grant UMO2014/15/B/ST5/ 02118 .

Open Access This article is licensed under a Creative Commons Attribution 4.0 International License, which permits use, sharing, adaptation, distribution and reproduction in any medium or format, as long as you give appropriate credit to the original author(s) and the source, provide a link to the Creative Commons licence, and indicate if changes were made. The images or other third party material in this article are included in the article's Creative Commons licence, unless indicated otherwise in a credit line to the material. If material is not included in the article's Creative Commons licence and your intended use is not permitted by statutory regulation or exceeds the permitted use, you will need to obtain permission directly from the copyright holder. To view a copy of this licence, visit http://creativecommons.org/licenses/by/4.0/.

\section{References}

1. R. Dominko, M. Bele, M. Gaberšček, A. Meden, M. Remškar, J. Jamnik, Electrochem. Commun. 8, 217 (2006)

2. R. Dominko, M. Bele, A. Kokalj, M. Gaberscek, J. Jamnik, J. Power Sources 174, 457 (2007)

3. Y.X. Li, Z.L. Gong, Y. Yang, J. Power Sources 174, 528 (2007)

4. M. Armand, C. Michot, N. Ravet, M. Simoneau, P. Hovington, US Patent 6, 085,015 (2000)

5. R. Dominko, J. Power Sources 184, 462 (2008) 
6. I. Belharouak, A. Abouimrane, K. Amine, J. Phys. Chem. C 113, 20733 (2009)

7. H. Duncan, A. Kondamreddy, P.H.J. Mercier, Y. Le Page, Y. AbuLebdeh, M. Couillard, P.S. Whitfield, I.J. Davidson, Chem. Mater. 23, 5446 (2011)

8. V. Aravindan, K. Karthikeyan, K.S. Kang, W.S. Yoon, W.S. Kim, Y.S. Lee, J. Mater. Chem. 21, 2470 (2011)

9. V. Aravindan, K. Karthikeyan, S. Ravi, S. Amaresh, W.S. Kim, Y.S. Lee, J. Mater. Chem. 20, 7340 (2010)

10. M. Boczar, M. Krajewski, M. Ratynski, B. Hamankiewicz, A. Czerwinski, Int. J. Electrochem. Sci. 13, 11636 (2018)

11. W. Liu, Y. Xu, R. Yang, Rare Metals 29, 511 (2010)

12. T. Muraliganth, K.R. Stroukoff, A. Manthiram, Chem. Mater. 22, 5754 (2010)

13. M. Kuezma, S. Devaraj, P. Balaya, J. Mater. Chem. 22, 21279 (2012)

14. D.M. Kempaiah, D. Rangappa, I. Honma, Chem. Commun. 48, $2698(2012)$

15. D. Rangappa, K.D. Murukanahally, T. Tomai, A. Unemoto, I. Honma, Nano Lett. 12, 1146 (2012)

16. M.K. Devaraju, T. Tomai, A. Unemoto, I. Honma, RSC Adv. 3, 608 (2013)

17. R.J. Gummow, N. Sharma, V.K. Peterson, Y. He, J. Solid State Chem. 188, 32 (2012)

18. G. Luo, J. He, X. Song, X. Huang, X. Yu, Y. Fang, D. Chen, J. Alloys Compd. 621, 268 (2015)
19. Y.J. Hao, Q.Y. Lai, J.Z. Lu, D.Q. Liu, X.Y. Ji, J. Alloys Compd. 439, 330 (2007)

20. K.S.W. Sing, Pure Appl. Chem. 54, 2201 (1982)

21. L.C. de Oliveira, C.A. Ribeiro, A.H. Rosa, W.G. Botero, J.C. Rocha, L.P. Cruz Romão, A. dos Santos, J. Braz. Chem. Soc. 20, 1135 (2009)

22. A. Kokalj, R. Dominko, G. Mali, A. Meden, M. Gaberscek, J. Jamnik, Chem. Mater. 19, 3633 (2007)

23. Q. Cheng, W. He, X. Zhang, M. Li, L. Wang, J. Mater. Chem. A 5, 10772 (2017)

24. C.A.J. Fisher, N. Kuganathan, M.S. Islam, J. Mater. Chem. A 1, 4207 (2013)

25. A. Guéguen, D. Streich, M. He, M. Mendez, F.F. Chesneau, P. Novák, E.J. Berg, J. Electrochem. Soc. 163, A1095 (2016)

26. M. Molenda, R. Dziembaj, M. Drozdek, E. Podstawka, L.M. Proniewicz, Solid State Ionics 179, 197 (2008)

27. M. Krajewski, B. Hamankiewicz, A. Czerwiński, Electrochim. Acta 219, 277 (2016)

28. M. Krajewski, B. Hamankiewicz, M. Michalska, M. Andrzejczuk, L. Lipinska, A. Czerwinski, RSC Adv. 7, 52151 (2017)

29. M. Ratyński, B. Hamankiewicz, M. Krajewski, M. Boczar, A. Czerwiński, RSC Adv. 8, 22546 (2018)

Publisher's Note Springer Nature remains neutral with regard to jurisdictional claims in published maps and institutional affiliations. 